\title{
PEMELIHARAAN POLA HIDUP SEHAT DAN PEMANFAATAN OBAT UNTUK PENCEGAHAN PENYAKIT DIABETES MELLITUS
}

\author{
Yedi Herdiana, Yoga Widhu Wardhana, dan Dudi Runadi \\ Fakultas Farmasi, Universitas Padjadjaran, Sumedang, 45363 \\ E-mail: y.herdiana@unpad.ac.id
}

\begin{abstract}
ABSTRAK. Penyakit diabetes merupakan penyakit degeneratif yang prevalensinya terus meningkat setiap tahun. Pengetahuan tentang penyakit, pola makan, dan pola hidup merupakan faktor penyebab peningkatannya. Desa Cinunuk merupakan wilayah urban, secara umum memiliki pola hidup perkotaan, yang mengalami kemudahan teknologi membuat perubahan pola hidup terutama pola makan dan kurangnya aktivitas fisik. Kondisi inilah yang menjadi ide penelitian pemeliharaan pola hidup dan pencegahan penyakit diabetes. Hasil penelitian ini menunjukkan tingkat pengetahuan responden $74,8 \%$ masuk kategori baik, sisanya $25,2 \%$ masuk katagori cukup. Pola makan masuk katagori baik 69,5\%, katagori cukup 20,5\%. Aktivitas fisik 80,5 \% temasuk katagori baik dan 19,5\% masuk kategori cukup. Adanya edukasi berkelanjutan tentang penyakit diabetes, faktor penyebab dan pola hidup sehat telah memberikan perubahan perbaikan pola hidup sehat. Setelah kegiatan KKN-PPM ini berakhir, diharapkan dapat meningkatkan pengetahuan masyarakat Desa Cinunuk mengenai penanganan penyakit diabetes.
\end{abstract}

Kata Kunci: Penyakit diabetes; Desa Cinunuk; Pola hidup; Penyuluhan

\begin{abstract}
Diabetes is a degenerative disease whose prevalence continues to increase every year. Knowledge of diseases, diet, and lifestyle is factor of the causes of increasement. Cinunuk village is an urban area, has an urban lifestyle, which has the ease of technology to make changes in lifestyle, especially diet and lack of physical activity. This condition is the idea of lifestyle change research and prevention of diabetes. The results of this study indicate that the level of knowledge of the respondents was $74.8 \%$ in the good category, the remaining $25.2 \%$ entered the medium category. The diet entered the good category $69.5 \%$, the medium category was $20.5 \%$. Physical activity $80.5 \%$ included good categories and $19.5 \%$ were in the medium category. The existence of joint gymnastic activities and continuing education has provided improved healthy lifestyles in the form of patient education and the establishment of appropriate early diagnosis and management. After the KKN-PPM activities ended, it was hoped that it could increase the knowledge of the Cinunuk Village community regarding the management of diabetes.
\end{abstract}

Key words: Diabetic deseases; Cinunuk Village; Lifestyle; counseling

\section{PENDAHULUAN}

Diabetes Melitus (DM) merupakan penyakit kronik yang tidak dapat disembuhkan, tetapi dapat dikendalikan. (Dewi, 2013). Tingginya DM merupakan penyakit gangguan metabolik menahun akibat produksi insulin atau sensitivitas insulin yang diproduksi. Insulin adalah hormon yang mengatur keseimbangan kadar gula darah. Akibatnya terjadi peningkatan konsentrasi glukosa di dalam darah atau disebut hiperglikemia. Terdapat dua kategori utama DM, yaitu tipe 1 dan tipe 2. (Idris dan Jafar, 2014). DM tipe 1, disebut insulin-dependent atau juvenile/childhood- onset diabetes, ditandai dengan kurangnya produksi insulin. DM tipe 2, disebut noninsulin-dependent atau adult-onset diabetes, disebabkan penggunaan insulin yang kurang efektif oleh tubuh. DM tipe 2 merupakan 90\% dari seluruh DM (Chandra dan Restuastuti, 2007; Purwandari, 2012; Januar dkk 2017; Toharin 2015).

Data terbaru dari WHO (Badan Kesehatan Dunia), Indonesia menduduki peringkat keempat terbesar dalam jumlah penyandang DM di dunia. Indonesia menempati urutan keempat setelah India, Cina, dan Amerika. Penderita DM di seluruh dunia hampir mencapai 150 juta orang dan di Indonesia mencapai 8,4 juta orang. Jumlah tersebut akan meningkat dua kali lipat pada tahun 2025 dan paling banyak terjadi di negara-negara berkembang, terutama di Asia Tenggara (Warapsari, 2010).
Penyakit DM tipe 2 merupakan penyakit degeneratif yang sangat terkait pola makan (Sukma, 2012). Penyerapan gula menyebabkan peningkatan kadar gula darah dan mendorong peningkatan sekresi hormon insulin untuk mengontrol kadar gula darah. Faktor lain yang memberikan andil sangat besar pada prevalensi penyakit diabetes melitus adalah pola hidup yang tidak sehat seperti kurangnya aktivitas fisik dan obesitas. Maka dari itu hal terpenting dari pengendalian DM adalah mengendalikan faktor risiko. (Rudi, 2017; Idris dan Jafar, 2014; Antara dkk., 2012; Chandra \& Restuastuti, 2007; Purwandari, 2012; Kusumadewi, 2015).

Kuliah Kerja Nyata Mahasiswa (KKNM) merupakan suatu bentuk pengabdian mahasiswa kepada masyarakat, untuk mengaplikasikan apa yang sudah diterima selama perkuliahan dan mendorong untuk mengatasi masalah yang ada di masyarakat.

Kondisi masyarakat di Indonesia mengalami perubahan yang sangat signifikan. Salah satu bentuk perubahan yang terjadi saat ini adalah kondisi ekonomi dan budaya. Kondisi inilah sebagai sumber pembelajaran dalam kegiatan KKNM.

Kegiatan KKN ini dalam untuk memecahkan masalah yang terjadi di masyarakat dan dengan $\mathrm{KKN}$ ini diharapkan dapat membantu perubahan masyarakat desa dan memaksimalkan potensi warganya dengan bantuan mahasiswa, adapun KKN terintegrasi PPM yang kami lakukan adalah "Perubahan Pola Hidup Sehat dan Penanganan Penyakit Diabetes”. 


\section{METODE}

Penelitian ini merupakan kuantitatif dengan menggunakan instrumen kuesioner. Informasi adalah survei tentang pengetahuan, pola makan dan aktivitas fisik. Instrumen penelitian adalah kuisoner dengan panduan wawancara. Analisis pengetahuan dan sikap dilakukan dengan cara skoring. Apabila jawaban responden benar diberi skor 1 dan jika jawaban salah diberi skor 0. Hasil skor total dikategorikan sebagai baik (70-100), cukup (5669) dan kurang (dibawah 55)

\section{HASIL DAN PEMBAHASAN}

Program KKNM Terintegrasi PPM Universitas Padjadjaran di Klinik Mitra Sehati di RW 04 Desa Cinunuk, Kecamatan Cileunyi, Kabupaten Bandung Jawa Barat. Materi terdiri dari Perubahan Pola Hidup Sehat dan Penanganan Penyakit Diabetes.

DM merupakan hal yang krusial di masyarakat, umumnya masyarakat belum paham betul pentingnya pola hidup sehat untuk terhindar dari DM. Ada banyak faktor penyebab DM antara lain difungsi pankreas, keturunan, infeksi virus, obesitas, pola makan yang buruk, rokok serta alkohol, stress berlebih dan faktor-faktor yang berhubungan dengan pola hidup yang tidak sehat. Diantara faktor penyebab kemungkinan kurangnya pengetahuan, pola makan dan aktivitas fisik yang semakin berkurang.

Salah satu faktor yang bisa menjadi pemicu DM di Desa Cinunuk adalah pola makan di daerah Desa Cinunuk mengandung karbohidrat tinggi. Komsumsi karbohidrat yang tinggi menjadi salah satu faktor resiko DM.

Maka dari itu perlu ditanamkan kepada masyarakat untuk dapat memanfaatkan hidup dengan baik dengan cara menerapkan pola hidup sehat agar terhindar dari berbagai penyakit khususnya penyakit DM.

Kami mengkaji bahwa di daerah RW 26 Desa Cinunuk, Kecamatan Cileunyi, Kabupaten Bandung Jawa Barat menurut Kepala Desa Cinunuk ada beberapa komunitas kesehatan yang memperdulikan tentang masalah kesehatan yaitu DM. Kemudian didaerah tersebut ada sebuah Klinik yang dapat mewadahi warga untuk dapat memahami pengetahuan tentang DM. Tim kami memutuskan untuk mengambil kesempatan tersebut yaitu dengan bekerja sama dengan komunitas DM tersebut untuk mengadakan penyuluhan namun dikemas dengan cara yang berbeda dan unik, yaitu dengan dengan penyuluhan yang dikemas dengan senam pagi dan acara2 kuis dan memberikan beberapa hadiah dan doorprize supaya semakin menarik. besar harapan sosialisasi yang dilakukan dapat membangun kesadaran masyarakat mengena pentingnya pola hidup sehat agar terhindar dari DM.

Inovasi PKM meliputi inovasi input, inovasi proses, inovasi produk (output) dan inovasi sistem PKM. Pada pengabdian ini ada dua inovasi yang dilakukan.
Pertama, inovasi dalam input PKM berwujud pelaku dan sumberdaya pendukung yang diaplikasikan. Sedangkan inovasi sumberdaya mencakup adanya skema PKM Prioritas Multitahun dan alokasi anggarannya. Kedua, inovasi dalam proses PKM, berupa inovasi metode atau pendekatan PKM, yaitu penyuluhan kepada masyarakat.

\section{Tabel 1. Karakteristik Responden}

\begin{tabular}{lccc}
\hline \multirow{2}{*}{ Jenis Kelamin } & \multicolumn{3}{c}{ Usia } \\
\cline { 2 - 4 } & $20-30$ & $31-40$ & $40-50$ \\
\hline Laki-laki & 2 & 5 & 4 \\
Perempuan & 8 & 10 & 21 \\
Total & 10 & 15 & 25 \\
\hline
\end{tabular}

Tabel 2. Interpretasi Hasil Responden

\begin{tabular}{cccc}
\hline Kategori & Pengetahuan & Pola makan & $\begin{array}{c}\text { Aktivitas } \\
\text { Fisik }\end{array}$ \\
\hline Baik & $74,8 \%$ & $66,5 \%$ & $80,5 \%$ \\
Cukup & $23,2 \%$ & $20,5 \%$ & $15,8 \%$ \\
Kurang & $2,0 \%$ & $3,0 \%$ & $4,7 \%$ \\
\hline
\end{tabular}

Hasil penelitian ini menunjukkan tingkat pengetahuan responden 74,8 \% masuk kategori baik, sisanya $25,2 \%$ masuk katagori cukup. Pola makan masuk katagori baik $69,5 \%$, katagori cukup 20,5\%. Aktivitas fisik 80,5\% temasuk katagori baik dan 19,5\% masuk kategori cukup.

Responden pada penelitian ini pada umumnya mengetahui dengan baik tentang penyakit. Walaupun masuk desa Cinunuk Wilayah RW 26, keberadaannya lebih dekat di area perkotaan, sehingga lebih mudah mengakses sumber informasi, internet ataupun media informasi. Kondisi seperti ini akan berpengaruh pada tingkat pengetahuan warga.

Hampir semua responden berada pada wilayah instalasi kesehatan berupa klinik, yang secara aktif memberikan edukasi dan pelayanan informasi tentang penyakit degeneratif. Sebagian warganya tergabung dalam klub senam sehat sehingga ada kegiatan rutin senam bersama. Pada lokasi ini terlihat ideal peran edukasi dari klinik kesehatan dan sikap pro aktif dari masyarakat untuk memelihara kesehatan.

Poin penting lainnya dari data yang diperoleh adalah penggunaan obat-obat antidiabetes yang benar. Penggunaan obat harus disertai dengan perubahan pola hidup sehat yang meliputi pola makan dan aktivitas fisik sudah mencukupi.

\section{SIMPULAN}

Penyuluhan terkait DM sangat berguna bagi warga. Dengan diadakannya penyuluhan ini, warga menjadi mengetahui betapa pentingnya menjaga pola hidup dan pola makan. Penyakit DM merupakan penyakit degeneratif yang 
makanan seperti karbohidrat/ gula, protein, lemak, dan energi yang berlebihan dapat menjadi faktor resiko awal kejadian DM, faktor lain yang memberikan andil sangat besar pada prevalensi penyakit DM melitus adalah gaya hidup yang tidak sehat seperti kurangnya aktivitas fisik, diet yang tidak sehat dan tidak seimbang serta obesitas. Maka dari itu hal terpenting dari pengendalian DM adalah mengendalikan faktor risiko.

Tujuan penting dari pengelolaan DM adalah memulihkan kekacauan metabolisme sehingga segala proses metabolik kembali normal. Oleh karena itu, diperlukan pemahaman terhadap warga akan pentingnya menjaga pola hidup sehat agar tehindar dari penyakit DM dan diperlukan pengetahuan tentang penanganannya, pengendalian pola makan dan aktifitas fisik. Pengelolaan instalasi kesehatan di RW 26 bisa menjadi model untuk pemeliharaan kesehatan di masyarakat sekitarnya.

\section{DAFTAR PUSTAKA}

Abil Rudi, H. N. K. (2017). Faktor Risiko yang mempengaruhi Kadar Gula darah Puasa Pada pengguna Layanan Laboratorium. Wawasan Kesehatan, 3.

Afindaningtryas Warapsari, K. S. D. (2010). Perilaku Sehat Pada Penderita Dibetes Melitus Tipe II Yang Telah Mengalami Retinopati Diabetika.

Andi Mardhiyah Idris, Nurhaedar Jafar, R. I. (2014). Diet Connection with Blood Sugar Levels Outpatient DM Type 2 in The Area of City Health Makassar Andi Mardhiyah Idris , Nurhaedar Jafar, Rahayu Indriasari Program Studi Ilmu Gizi Fakultas Kesehatan.

Antara, H., Sosial, D., Perilaku, D., Pada, M., Mellitus, D., Kelurahan, D. I., ... Keperawatan, I. (2012). Hubungan Antara Dukungan Sosial Keluarga dengan Perilaku Makan Pada Penderita Diabetes Melitu di Keluarahan Prawirodirjan Yogyakarta. Yogyakarta.

Chandra, F., \& Restuastuti, T. (2007). Faktor-Faktor Risiko Pasien Diabetes Melitus. Berita Kedokteran Masyarakat, 23(3), 142-147.

Dewi, R. P. (2013). Faktor Risiko Perilaku yang Berhubungan dengan Kadar Gula Darah pada Penderita Diabetes Melitus Tipe 2 di RSUD Kabupaten Karanganyar. Jurnal Kesehatan Masyarakat, 2(3), 1-11.

Henny Purwandari, M. K. S. (2012). Hubungan Perilaku Diet dengan Kadar Gula Darah Pada Penderita Diabetes Melitus Tipe II (pp. 11-19).

Januar, A., Putra, P., Widayati, N., \& Sutawardana, J. H. (2017). Hubungan Diabetes Distress dengan Perilaku Perawatan Diri pada Penyandang Diabetes Melitus Tipe 2 di Wilayah Kerja Puskesmas Rambipuji Kabupaten Jember ( Correlation between Diabetes Distress and Self- care Behaviour in People with Type 2 Diabetes Mellitu. E-Jurnal Pustaka Kesehatan, 5(1), 185-192.

Kusumadewi, M. D. (n.d.). Peran Stresor Harian , Optimisme dan Regulasi Diri terhadap Kualitas Hidup Individu dengan Diabetes Melitus Tipe 2. Jurnal Psikologi Islam, 8(1), 43-61.

Sukma, A. P. (2012). Kesadaran kesehatan dan gaya hidup sehat dengan sikap konsumen pada makanan organik skripsi. Yogyakarta.

Syamsi Nur Rahman Toharin, Widya Hary Cahyati, I. Z. (2015). Hubungan modifikasi gaya hidup dan Kepatuhan Konsumsi Obat Antidibetik Dengan Kadar Gula Darah Pada Penderita DM tip II di RS QIM Batang 2013. Unnes Journal of Public Health, 4(2), 153-161. 